Syntax Literate: Jurnal Ilmiah Indonesia p-ISSN: 2541-0849

e-ISSN: 2548-1398

Vol. 6, No. 1, Januari 2021

\title{
PENGARUH EDUKASI FARMASIS TERHADAP HASIL TERAPI DAN KUALITAS HIDUP PASIEN PROLANIS DIABETES MELITUS TIPE 2
}

\author{
Dewi Laxmi, Shirly Kumala, Prih Sarnianto dan Asnah Tarigan \\ Magister Farmasi Universitas Pancasila, Jakarta, Indonesia \\ Email: dewilaxmilaxmi@yahoo.com,fskumala@yahoodan prih1488@gmail.com
}

\begin{abstract}
Diabetes Mellitus is a chronic disease or metabolic disorder with multiple etiologies characterized by high blood glucose levels accompanied by disorders of carbohydrate, protein, and lipid metabolism as a result of insufficient insulin function. There should be proper, integrated and sustainable DM management so as to control blood glucose and achieve optimal quality of life. This study aims to increase knowledge and therapy compliance of patients with type II diabetes mellitus through the existence of pharmacist counseling in order to achieve optimal therapy results and quality of life. This was a quasi-experimental study with a Two Group Pretest-Posttest design. The results of the study in the intervention group showed that after Wilcoxon test, there were an increase in the mean value of knowledge, an increase in the value of compliance, a decrease in fasting blood sugar (FBS) levels, a decrease in Postprandial Glucose (PPG) levels and a significant increase in the value of quality of life. Meanwhile in the control group, an increase in the mean value of knowledge, an increase in the value of compliance, a decrease in the FBS levels, and an increase in the value of quality of life were not signifocant, only a decrease in the PPG levels that was significant. From the results of the Mann Whitney test, there were significant differences between the intervention group and the control group on the level of knowledge, compliance, PPG levels, and quality of life, while there was no significant difference in FBS levels. From the Spearmen's test, there was evidenced a relationship between knowledge, compliance, blood glucose levels, and quality of life. It can be concluded that counseling provided by pharmacists could increase knowledge and compliance of patients with type II diabetes mellitus in order to achieve optimal therapy results and quality of life.
\end{abstract}

Keywords: knowledge, compliance, FBS, PPG, quality of life, education

\begin{abstract}
Abstrak
Diabetes Mellitus merupakan suatu penyakit atau gangguan metabolisme kronis dengan multi etiologi yang ditandai dengan tingginya kadar glukosa darah disertai dengan gangguan metabolisme karbohidrat, protein, dan lipid sebagai akibat insufiensi fungsi insulin. Penyakit DM memerlukan pengelolaan secara benar, terpadu, dan berkesinambungan sehingga glukosa darah dapat terkontrol dan kualitas hidup yang optimal akan tercapai. Tujuan penelitian ini adalah dengan adanya konseling farmasis
\end{abstract}


dapat meningkatkan pengetahuan dan kepatuhan pasien diabetes melitus tipe 2 sehingga tercapai hasil terapi kualitas hidup yang optimal. Penelitian ini menggunakan metode quasi eksperimental dengan desain Two Group Pretest-Posttest. Hasil penelitian pada kelompok intervensi setelah diuji Wilcoxon terjadi peningkatan nilai rata-rata pengetahuan, peningkatan nilai kepatuhan, penurunan kadar gula darah puasa (GDP), penurunan kadar Gula Darah Setelah Makan (GDPP) dan peningkatan nilai kualitas hidup yang signifikan, sedangkan pada kelompok kontrol peningkatan nilai rata-rata pengetahuan, peningkatan nilai kepatuhan, penurunan kadar GDP, dan peningkatan nilai kualitas hidup tidak signifikan, hanya pada penurunan kadar GDPP yang signifikan. Dari hasil uji Mann Whitney ada perbedaan bermakna antara kelompok intervensi dan kelompok kontrol pada tingkat pengetahuan, kepatuhan, GDPP, dan kualitas hidup, sedangkan pada GDP tidak ada perbedaan yang bermakna. Dengan uji Spearmen's terlihat adanya hubungan antara pengetahuan, kepatuhan, kadar gula darah, dan kualitas hidup. Dapat disimpulkan bahwa dengan adanya konseling oleh farmasis dapat meningkatkan pengetahuan, dan kepatuhan pasien diabetes melitus tipe II sehingga tercapai hasil terapi dan kualitas hidup yang optimal.

Kata kunci: pengetahuan, kepatuhan, GDP, GDPP, kualitas hidup, edukasi

Coresponden Author

Email: dewilaxmilaxmi@yahoo.com Artikel dengan akses terbuka dibawah lisensi

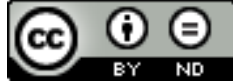

\section{Pendahuluan}

Pada tahun 2000, Word Health Organization (WHO) memprediksi sedikitnya 171 juta orang di seluruh dunia menderita diabetes mellitus (DM), atau sekitar 2,8\% dari total populasi,dan pada 2030 angka ini akan bertambah menjadi 366 juta atau sekitar 4,4\% dari populasi dunia. Benua Asia dan Afrika merupakan benua yang paling tinggi peningkatan prevalensi DM sebagai akibat dari tren urbanisasi dan perubahan gaya hidup, seperti pola makan "Western-style" yang tidak seimbang (Federation, 2015).

Menurut data Riset Kesehatan Dasar (Riskesdas) tahun 2013, prevalensi DM di Indonesia berdasarkan diagnosis dokter adalah sebesar 2,1\%, dimana prevalensi terdiagnosis dokter tertinggi pada daerah Sulawesi Tengah $(3,7 \%)$ dan paling rendah pada daerah Jawa Barat (0,5\%). Untuk daerah Lampung sendiri, prevalensi DM yang terdiagnosis dokter adalah sebesar 0,8\%. Data ini juga menunjukkan prevalensi DM yang meningkat sesuai dengan bertambahnya umur, prevalensi DM yang cenderung lebih tinggi wanita dibanding laki-laki, dan prevalensi yang lebih tinggi di wilayah perkotaan dibandingkan di pedesaan (Indonesia, 2013).

Kota Bandar Lampung memiliki 30 puskesmas yang terdiri dari 12 Puskesmas Rawat Inap dan 18 Puskesmas Rawat Jalan. Puskesmas Satelit dan Puskesmas Kedaton merupakan dua Puskesmas Rawat Inap yang terakrediasi Utama, dan kedua puskesmas ini memiliki 
populasi pasien DM terbanyak di Kota Bandar Lampung. Di Puskesmas Satelit dan Puskesmas Kedaton, penyakit DM merupakan penyakit dengan urutan ke 7 dari 10 penyakit teratas, dan kedua puskesmas ini melaksanakan Prolanis dengan baik (Lampung, 2015).

Diabetes mellitus merupakan suatu penyakit atau gangguan metabolisme kronis dengan multi etiologi yang ditandai dengan tingginya kadar glukosa darah disertai dengan gangguan metabolisme karbohidrat, protein, dan lipid sebagai akibat insufiensi fungsi insulin. Insufisiensi insulin ini disebabkan oleh kurangnya responsif sel-sel tubuh terhadap insulin, dan disebut juga dengan DM Tipe 2. Penyakit DM memerlukan pengelolaan secara benar, terpadu, dan berkesinambungan sehingga glukosa darah dapat terkendali dan kualitas hidup yang optimal tercapai. Penatalaksanaan DM dipengaruhi beberapa faktor, dan bila faktor-faktor tersebut tidak dapat terpenuhi dapat menyebabkan kegagalan dalam terapi. Kegagalan terapi DM terutama disebabkan oleh kurangnya kemampuan pasien dalam melakukan manajemen diri (self management) seperti mengatur pola makan dan olahraga, rendahnya tingkat pengetahuan pasien tentang DM, serta ketidakpatuhan dalam menggunakan obat anti-diabetes (OAD). Konseling singkat (brief counseling) merupakan salah satu bentuk pendekatan yang dapat digunakan, dimana lebih berfokus pada perubahan yang diinginkan pasien bukan pada penyebab dari problem pasien. Konseling yang diberikan secara berkesinambungan, dapat meningkatkan pengetahuan, cara penanganan, kepatuhan dalam menjalankan keteraturan minum obat oleh pasien, sehingga hal tersebut akan sangat mempengaruhi kestabilan glukosa dalam darah dan tercapainya kualitas hidup yang optimal (Creed et al., 2001) Untuk mencapai kualitas hidup yang optimal pada pasien, pemerintah RI, dalam hal ini Badan Penyelenggara Jaminan Sosial Kesehatan (BPJS-K), membuat Program Pengelolaan Penyakit Kronis (Prolanis). Aktivitas Prolanis meliputi konsultasi medis peserta Prolanis, konseling kelompok peserta Prolanis, remender melalui SMS Gateway, dan aktivitas klub. Prolanis biasanya dilakukan di fasilitas kesehatan tingkat pertama, yaitu rumah sakit tipe D, klinik, dokter keluarga, dan puskesmas.

Data yang diperoleh dari beberapa puskesmas di Bandar Lampung dimana pasien DM menempati urutan terbanyak dibandingkan penyakit lainnya, sehingga dipandang perlu dilakukan kajian mendalam terkait konseliing yang dilakukan pada pasien DM agar mereka patuh dan teratur minum obat sehingga gula darah mereka terkontrol dan stabil serta kualitas hidup mereka lebih baik. Karena meskipun sudah dilakukan layanan prolanis, edukasi farmasis belum optimal, sehingga perlu dilakukan penelitian untuk mengetahui pengaruh edukasi tersebut terhadap pengetahuan dan kepatuhan pasien. Sebagaimana tujuan penelitian ini adalah dengan adanya konseling farmasis dapat meningkatkan pengetahuan dan kepatuhan pasien diabetes melitus tipe 2 sehingga tercapai hasil terapi dan kualitas hidup yang optimal.

Diabetes tidak hanya menyebabkan kematian premature di seluruh dunia. Penyakit ini juga menjadi penyebab utama kebutaan, penyakit jantung dan gagal ginjal. Organisasi 
International Diabetes Federation (IDF) memperkirakan sedikitnya terdapat 463 juta orang pada usia 20-79 tahun di dunia menderita diabetes pada tahun 2019 atau setara dengan angka prevalensi sebesar 9,3\% dari total penduduk pada usia yang sama. Berdasarkan jenis kelamin, IDF memperkirakan prevalensi diabetes di tahun 2019 yaitu 9\%. Pada perempuan dan 9,65\% pada laki-laki. Prevalensi diabetes diperkirakan meningkat seiring penambahan umur penduduk menjadi $19,9 \%$ atau 111,2 juta orang pada umur 65-79 tahun. Angka diprediksi terus meningkat hingga mencapai 578 juta di tahun 2030 dan 700 juta di tahun 2045. (Pusat Data dan Informasi Kementerian Kesehatan RI, 2020)

Mengingat prevalensi diabetes diatas, penulis berharap penelitian ini bermanfaat untuk masyarakat. Karena dengan adanya edukasi yang dilakukan oleh apoteker kepada pasien diabetes melitus tipe 2, pasien menjadi lebih tertib, teratur dan patuh dalam menjalani terapinya. Mereka dapat beraktivitas normal dengan kualitas hidup yang baik serta tidak ada komplikasi penyakit lainnya. Berdasarkan latar belakang di atas, maka peneliti tertarik untuk melakukan penelitian tentang Pengaruh Konseling Farmasis terhadap Hasil Terapi dan Kualitas Hidup Pasien Prolanis DM Tipe 2 di Puskesmas Satelit dan Kedaton Bandar Lampung.

\section{Metode Penelitian}

Desain penelitian ini adalah quasi eksperimental dengan desain Two Group Pre Test - Post Test. Populasi penelitian adalah pasien DM tipe 2 peserta Program Pengelolaan Penyakit Kronis (Prolanis) di Puskemas Satelit dan Puskesmas Kedaton Kota Bandar Lampung.Sampel diperoleh dengan metode purposive sampling pada Puskesmas Satelit sebagai kelompok intervensi sebanyak 40 pasien dan consecutive sampling pada Puskesmas Kedaton sebagai kelompok kontrol sebanyak 40 pasien. Pengumpulan data pre test dengan mengambil data primer dan sekunder pasien pada pertemuan pertama dan pengumpulan data post test diambil secara prospektif melalui wawancara tatap muka, kuesioner pada pasien DM tipe 2 peserta Prolanis selama tiga bulan dengan mengamati pengetahuan tentang penyakit, kepatuhan minum obat, hasil terapi dan kualitas hidup.

Alat penelitian yang digunakan pada penelitian ini adalah pengukur glukosa darah dan kuisioner. Kusioner yang digunakan adalah ADL Knowledge, MMAS, dan SF 36. Analisis statistik dan pengolahan data dilakukan dengan menggunakan program SPSS versi 23. Analisis statistik yang digunakan adalah analisis univariat digunakan untuk mendapatkan gambaran distribusi frekuensi (proporsi) karakteristik pasien berdasarkan demografi. Analisa dengan uji Mann Withney untuk melihat perbedaan ADL Knowledge, MMAS, hasil terapi dan SF 36 pada pasing-masing puskesmas dan antar puskesmas. Analisa dengan uji Wilcoxon untuk mengetahui perbedaan skor ADL Knowledge, MMAS, hasil terapi dan SF 36 kunjungan pertama (pre) dengan kunjungan kedua (post) pada masing-masing puskesmas. Analisa korelasi hubungan antara hasil terapi dan kualitas hidup 
Dewi Laxmi, Shirly Kumala, Prih Sarnianto dan Asnah Tarigan

dengan confounding factor menggunakan uji statistik non parametrik Spearmans rho correlation.

\section{Hasil dan Pembahasan}

\section{Sosiodemografi}

Data sosiodemografi pasien DM tipe 2 dikelompokkan berdasarkan usia, pendidikan, pekerjaan, jenis kelamin dan durasi menderita diabetes mellitus sebagaimana disajikan tabel 1. Karakteristik usia dalam penelitian ini menunjukkan responden dengan usia 56 - 65 tahun merupakan responden yang paling banyak pada kelompok kontrol maupun kelompok intervensi yaitu 22 pasien atau $55 \%$ pada kelompok kontrol dan 26 pasien atau 65\% pada kelompok intervensi, sedangkan responden dengan usia 46-55 tahun merupakan responden yang paling sedikit pada kelompok kontrol maupun kelompok intervensi, yaitu 3 pasien atau 7,5\% pada kelompok kontrol dan 4 pasien atau $10 \%$ pada kelompok intervensi. Usia merupakan variabel yang penting dalam penyakit DM karena semakin tinggi usia akan terjadi peningkatan intoleransi glukosa. Adanya penuaan menyebabkan berkurangnya kemampuan sel $\beta$ pankreas dalam memproduksi insulin. Selain itu pada individu yang lebih tua terdapat penurunan aktivitas mitokondria di sel-sel otot sebesar 35\%. Hal ini berhubungan dengan peningkatan kadar lemak di otot sebesar $30 \%$ dan memicu terjadinya resistensi insulin.

Berdasarkan karakteristik pendidikan responden, pendidikan sekolah dasar merupakan yang paling banyak pada kelompok kontrol maupun kelompok intervensi yaitu 18 pasien atau $45 \%$ pada kelompok kontrol dan 17 pasien atau 42,5\% pada kelompok intervensi, sedangkan responden dengan pendidikan perguruan tinggi merupakan responden yang paling sedikit pada kelompok kontrol maupun kelompok intervensi, yaitu 5 pasien atau 12,5\% pada kelompok kontrol dan 2 pasien atau $5 \%$ pada kelompok intervensi. Tingkat pengetahuan pada setiap individu salah satunya dapat dipengaruhi oleh status pendidikan dimana kemampuan dalam mendapatkan informasi tentang penyakit-penyakit secara umum lebih banyak. Dengan adanya pengetahuan tersebut orang akan memiliki kesadaran dalam menjaga kesehatannya. Semakin tinggi tingkat pendidikan seseorang berbanding lurus dengan semakin tingginya kemampuan orang tersebut untuk mengatur pola hidupnya agar tetap sehat. Semakin tinggi tingkat pendidikan seseorang berbanding lurus dengan semakin tingginya kemampuan orang tersebut untuk mengatur pola hidupnya agar tetap sehat. Status pendidikan merupakan salah satu faktor yang mempengaruhi tingkat pengetahuan seseorang. Makin tinggi tingkat pendidikan seseorang, maka kemampuan memperoleh informasi tentang penyakit umumnya lebih banyak (Mongisidi, 2014). 
Tabel 1

Karakteristik Pasien Diabetes mellitus

\begin{tabular}{|c|c|c|c|c|}
\hline \multirow{3}{*}{ Variabel } & \multicolumn{4}{|c|}{ Kelompok } \\
\hline & \multicolumn{2}{|c|}{ Kontrol } & \multicolumn{2}{|c|}{ Intervensi } \\
\hline & $n=40$ & $\%$ & $n=40$ & $\%$ \\
\hline \multicolumn{5}{|l|}{ Usia } \\
\hline a. 36 - 45 tahun & 3 & 7,5 & 4 & 10 \\
\hline b. 46 - 55 tahun & 15 & 37,5 & 10 & 25 \\
\hline c. 56 - 65 tahun & 22 & 55 & 26 & 65 \\
\hline \multicolumn{5}{|l|}{ Pendidikan } \\
\hline a. Sekolah Dasar & 18 & 45 & 17 & 42,5 \\
\hline b. SMP & 10 & 25 & 16 & 40 \\
\hline c. SMA & 7 & 17,5 & 5 & 12,5 \\
\hline d. Perguruan Tinggi & 5 & 12,5 & 2 & 5 \\
\hline \multicolumn{5}{|l|}{ Pekerjaan } \\
\hline a. Ibu rumah tangga & 24 & 60 & 27 & 67,5 \\
\hline b. Swasta & 16 & 40 & 13 & 32,5 \\
\hline \multicolumn{5}{|l|}{ Jenis kelamin } \\
\hline a. Laki-laki & 16 & 40 & 13 & 32,5 \\
\hline b. Perempuan & 24 & 60 & 27 & 67,5 \\
\hline \multicolumn{5}{|l|}{$\begin{array}{l}\text { Durasi } \\
\text { diabetes mellitus }\end{array}$} \\
\hline a. $1-5$ tahun & 29 & 72,5 & 27 & 67,5 \\
\hline b. $6-10$ tahun & 7 & 17,5 & 11 & 27,5 \\
\hline c. $>10$ tahun & 4 & 10 & 2 & 5 \\
\hline
\end{tabular}

Karakteristik pekerjaan ibu rumah tangga merupakan yang paling banyak pada kelompok kontrol maupun kelompok intervensi yaitu 24 pasien atau $60 \%$ pada kelompok kontrol dan 27 pasien atau 67,5\% pada kelompok intervensi, sedangkan responden dengan pekerjaan wiraswasta merupakan yang paling sedikit pada kelompok kontrol maupun kelompok intervensi, yaitu 16 pasien atau $40 \%$ pada kelompok kontrol dan 13 pasien atau 32,5\% pada kelompok intervensi.

Berdasarkan Pusdatin diabetes mellitus yang dikeluarkan oleh Kemenkes tahun 2015 pekerjaan ibu rumah tangga menempati posisi nomor dua tertinggi yaitu 7,4\% setelah pekerjaan lain-lain 9,3\%. Menurut Bentteng R, dkk aktifitas fisik akan membuat kadar insulin lebih meningkat, sedangkan pekerjaan ibu rumah tangga hanyalah menyapu, mencuci dan memasak yang tergolong dalam aktifitas ringan. Hal ini juga didukung oleh penelitian yang dilaksanakan oleh Blkau et al (2008), pada 13 negara di Eropa disimpulkan bahwa akumulasi aktivitas fisik sehari-hari merupakan faktor utama yang menentukan sensitivitas insulin. Tanpa adanya kombinasi dengan olahraga yang cukup maka kecenderungan pekerjaan ibu rumah tangga lebih banyak dalam populasi diabetes mellitus di masyarakat.

Karakteristik jenis kelamin perempuan merupakan yang paling banyak pada kelompok kontrol maupun kelompok intervensi yaitu 24 pasien atau $60 \%$ pada 
kelompok kontrol dan 27 pasien atau 67,5\% pada kelompok intervensi, sedangkan responden dengan jenis kelamin laki-laki responden yang paling sedikit pada kelompok kontrol maupun kelompok intervensi, yaitu 16 pasien atau $40 \%$ pada kelompok kontrol dan 13 pasien atau 32,5\% pada kelompok intervensi. Jenis kelamin perempuan lebih beresiko mengidap diabetes mellitus karena secara fisik perempuan memiliki peluang peningkatan indeks masa tubuh yang lebih besar. Sindroma siklus bulanan (premenstrual syndroma), pasca-menopouse yang membuat distribusi lemak tubuh menjadi mudah terakumulasi akibat proses hormonal tersebut sehingga wanita beresiko menderita DM tipe 2 (Irawan, 2010).

Diabetes mellitus merupakan penyakit menahun yang disandang penderitanya seumur hidup. Pengontrolan kadar glukosa sangat penting untuk menekan tingkat keparahan penyakit itu sendiri. Dalam penelitian ini durasi diabetes mellitus dibagi menjadi 3 kategori yaitu 1-5 tahun, 6-10 tahun dan lebih dari 10 tahun. Dari data yang ada bahwa kategori 1-5 tahun merupakan durasi DM yang tertinggi pada kelompok kontrol maupun kelompok intervensi yaitu 29 pasien atau 72,5\% pada kelompok kontrol dan 27 pasien atau 67,5\% pada kelompok intervensi. Lamanya menderita DM berpengaruh terhadap keyakinan pasien dalam perawatan yang tentunya berpengaruh pada kualitas hidupnya. Pasien yang lebih lama telah menderita DM memiliki efikasi

diri yang baik, hal itu disebabkan karena pasien telah berpengalaman dalam mengelola penyakitnya.

2. Pengaruh Edukasi Farmasis terhadap Pengetahuan, Kepatuhan, Kadar Glukosa Darah, dan Kualitas Hidup

\section{a. Pengetahuan}

Dari hasil uji wilcoxon test pada kelompok intervensi diperoleh nilai p-value adalah $0,000(\mathrm{p}<0,05)$ yang menunjukkan terdapat perbedaan nilai pengetahuan yang signifikan sebelum dan setelah konseling farmasis, sedangkan pada kelompok kontrol diperoleh nilai signifikansi sebesar 0,083 ( $p>0,05)$ yang menunjukkan tidak terdapat perbedaan yang signifikan pada kelompok kontrol pada hasil pengukuran nilai pengetahuan sebelum dan sesudah dilakukan penelitian. Dari hasil uji mann whitney diperoleh signifikansi sebesar $0,000(\mathrm{p}<0,05)$ yang menunjukkan bahwa ada perbedaan nilai pengetahuan antara kelompok kontrol dan kelompok intervensi. Setelah diberikan konseling farmasis selama tiga bulan, sebagian besar responden kelompok internesi menunjukkan peningkatan pengetahuan, seperti pengertian diabetes melitus, klasifikasi, faktor resiko, gejala klinik, komplikasi, terapi obat dan non obat, pencegahan, serta pentingnya konsultasi. Peningkatan rata-rata nilai pengetahuan terjadi setelah konseling farmasis dan adanya perbedaan pengetahuan yang signifikan. Hal ini menunjukkan bahwa tujuan konseling farmasis untuk membimbing dan mendidik pasien sehingga pengetahuan pasien mengenai capaian 
tujuan terapi dan mutu pengobatan pasien akan meningkat sesuai teori dapat direalisasikan.

\section{Tabel 2}

Hasil uji beda antara pengetahuan sebelum dan sesudah intervensi farmasis pada kelompok kontrol dan intervensi

\begin{tabular}{|c|c|c|c|c|c|c|}
\hline \multirow{3}{*}{ Pengetahuan } & \multicolumn{6}{|c|}{ Kelompok } \\
\hline & \multicolumn{3}{|c|}{$\begin{array}{c}\text { Kontrol }(\mathrm{n}=40) \\
\text { Puskesmas Kedaton }\end{array}$} & \multicolumn{3}{|c|}{$\begin{array}{l}\text { Intervensi }(\mathbf{n}=40) \\
\text { Puskesmas Satelit }\end{array}$} \\
\hline & pre & post & Sig & pre & post & Sig \\
\hline Rata-rata & 27,525 & 27,6 & $\mathbf{0 , 0 8 3}$ & 26,625 & 31,525 & 0,000 \\
\hline $50 \%$ rata-rata & 13,76 & 13.8 & & 13,31 & 15,76 & \\
\hline $75 \%$ rata-rata & 20,64 & 20,7 & & 19,96 & 23,6 & \\
\hline Tinggi (>75\% rata-rata) & 37 & 37 & & 40 & 40 & \\
\hline $\begin{array}{l}\text { Sedang }(50 \%-\leq 75 \% \\
\text { rata-rata) }\end{array}$ & 3 & 3 & & 0 & 0 & \\
\hline Rendah $(<50 \%$ rata-rata $)$ & 0 & 0 & & 0 & 0 & \\
\hline
\end{tabular}

Tabel 3

Hasil perbedaan pengetahuan pada kelompok kontrol dan intervensi dengan uji Mann Whitney

\begin{tabular}{ccccc}
\hline \multirow{2}{*}{ Variabel } & & \multicolumn{2}{c}{ Kelompok } & \multirow{2}{*}{ Sig } \\
\cline { 2 - 4 } & & $\begin{array}{c}\text { Kontrol (n=40) } \\
\text { Puskesmas Kedaton }\end{array}$ & $\begin{array}{c}\text { Intervensi (n=40) } \\
\text { Puskesmas Satelit }\end{array}$ & \\
\hline \multirow{2}{*}{$\begin{array}{c}\text { Nilai rata-rata } \\
\text { ADL } \\
\text { (pengetahuan) }\end{array}$} & Pre & 27,525 & 26,625 & \\
\cline { 2 - 5 } & $\begin{array}{c}\text { Rost } \\
\text { nilai selisih }\end{array}$ & 0,075 & 31,525 & \multirow{0}{0,000}{} \\
\hline
\end{tabular}

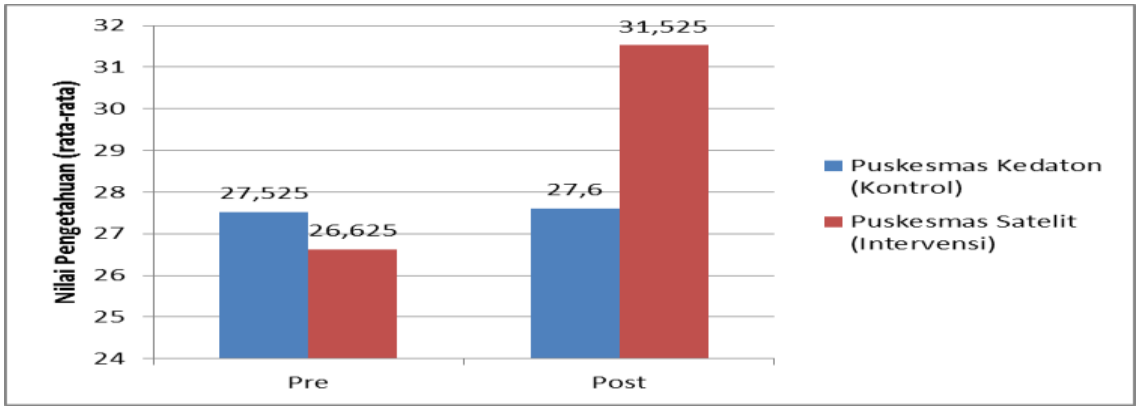

Grafik 1

Perbedaan pengetahuan pasien berdasarkan rerata sebelum dan setelah konseling farmasis

\section{b. Kepatuhan}

Dari hasil uji wilcoxon test pada kelompok intervensi diperoleh nilai p-value adalah $0,000(\mathrm{p}<0,05)$ yang menunjukkan terdapat perbedaan nilai kepatuhan yang 
signifikan sebelum dan setelah pasien diberikan konseling farmasis, sedangkan pada kelompok kontrol diperoleh nilai signifikansi sebesar 0,685 ( $p>0,05)$ yang menunjukkan tidak terdapat perbedaan yang signifikan pada kelompok kontrol pada hasil pengukuran nilai kepatuhan sebelum dan sesudah dilakukan penelitian. Dari hasil uji mann whitney diperoleh signifikansi sebesar $0,000 \quad(\mathrm{p}<0,05)$ yang menunjukkan bahwa ada perbedaan nilai kepatuhan antara kelompok kontrol dan kelompok intervensi.

Tabel 4

Hasil uji beda antara kepatuhan sebelum dan sesudah intervensi farmasis pada kelompok kontrol dan intervensi

\begin{tabular}{|c|c|c|c|c|c|c|}
\hline \multirow{3}{*}{ Kepatuhan } & \multicolumn{6}{|c|}{ Kelompok } \\
\hline & \multicolumn{3}{|c|}{$\begin{array}{c}\text { Kontrol }(\mathrm{n}=40) \\
\text { Puskesmas Kedaton }\end{array}$} & \multicolumn{3}{|c|}{$\begin{array}{l}\text { Intervensi }(n=40) \\
\text { Puskesmas Satelit }\end{array}$} \\
\hline & pre & post & Sig & pre & post & Sig \\
\hline Rata-rata & $\begin{array}{r}5,15 \\
\pm 1,14 \\
\end{array}$ & $\begin{array}{c}5,1 \\
\pm 0,9 \\
\end{array}$ & 0,685 & $\begin{array}{r}5,125 \\
\pm 1,11 \\
\end{array}$ & $\begin{array}{r}6,725 \\
\pm 0,64 \\
\end{array}$ & 0,000 \\
\hline Tinggi $(\geq 8)$ & 0 & 0 & & 0 & 4 & \\
\hline Sedang $(6-<8)$ & 16 & 12 & & 14 & 36 & \\
\hline Rendah $(<6)$ & 24 & 28 & & 26 & 0 & \\
\hline
\end{tabular}

Tabel 5

Hasil perbedaan kepatuhan pada kelompok kontrol dan intervensi dengan uji Mann Whitney

\begin{tabular}{ccccc}
\hline \multirow{2}{*}{ Variabel } & & \multicolumn{2}{c}{ Kelompok } & \multirow{2}{*}{ Sig } \\
\cline { 2 - 4 } & & Kontrol & Intervensi & \multirow{2}{*}{$\begin{array}{c}\text { Pre } \\
\text { Nilai rata-rata MMAS } \\
\text { (kepatuhan) }\end{array}$}
\end{tabular}

Perbedaan nilai kepatuhan antara kelompok intervensi dan kelompok kontrol menggambarkan bahwa konseling yang diberikan kepada pasien prolanis DM tipe 2 dapat meningkatkan kepatuhan pasien tersebut. Peningkatan kepatuhan yang terjadi setelah konseling menunjukkan bahwa informasi mengenai yang didapatkan setelah konseling yang dilakukan oleh farmasis dapat berdampak positif terhadap perubahan perilaku yang meningkatkan kepatuhan. Dengan pasien mengetahui mekanisme kerja obat dan dampak atau resiko bila minum obat tidak sesuai aturan melalui konseling dengan penjelasan yang memadai dan adanya tanya jawab akan memotivasi mereka untuk meningkatkan kepatuhan. MMAS adalah hasil pengembangan dari MMS yang dapat meningkatkan sensitivitas pengukuran kepatuhan menggunakan obat karena item pertanyaan dan skala lebih spesifik. MMAS sudah divalidasi dan digunakan untuk penelitian kepatuhan obat pada 
pasien hipertensi dan pasien diabetes (Morisky, Ang, Krousel-Wood, \& Ward, 2008).

Hasil penelitian ini sejalan dengan hasil penelitian yang dilakukan oleh Rifqi R., dkk., di Puskesmas Srandakan Bantul bahwa ada perbedaan yang signifikan antara kepatuhan pasien dalam penggunaan obat sebelum dan setelah pelaksanaan home care pada pasien DM tipe 2 dengan komplikasi hipertensi (Rifqi R, Chlara N, 2015) Penelitian di Puskesmas Kramat Jati Jakarta Timur yang dilakukan oleh Voni $\mathrm{N}$., diperoleh hasil ada perbedaan yang signifikan sebelum dan setelah pemberian intervensi farmasi pada kepatuhan minum obat pasien DM tipe 2 (N, 2015).

Pada penelitian di Puskesmas Bambanglipuro dan Puskesmas Pundong diperoleh hasil penelitian bahwa terdapat pengaruh antara pemberian konseling farmasi dengan tingkat kepatuhan penggunaan obat serta hasil terapi pasien DM tipe 2. Juga terdapat hubungan antara tingkat kepatuhan dengan hasil terapi (Zakaria, Mohamed, Ab Rahid, \& Rose, 2017). Hasil penelitian di Rumah Sakit Mayapada Tanggerang menyatakan bahwa pemberian booklet dapat meningkatkan pengetahuan dan kepatuhan minum obat pada pasien DM Tipe 2 (Merlin, Arozal, Sauriasari, \& Keban, 2017).

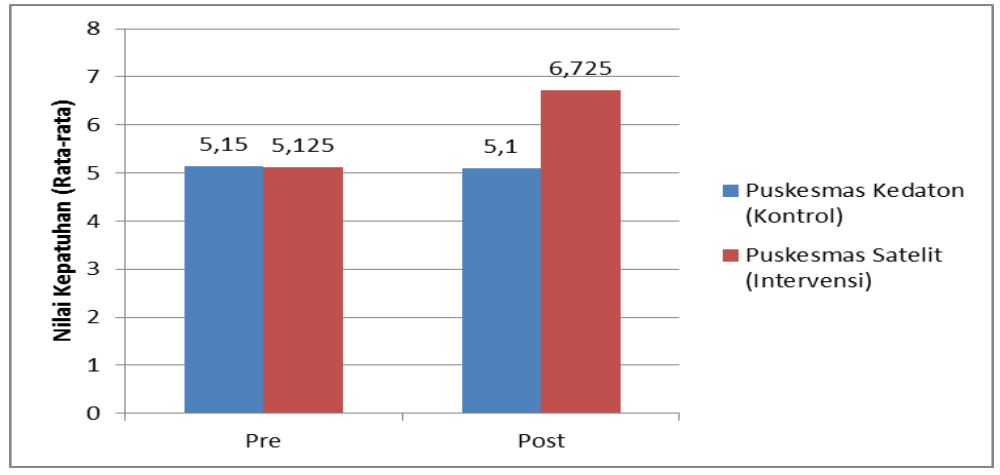

Grafik 2

Perbedaan kepatuhan pasien berdasarkan rerata sebelum dan setelah konseling farmasis

c. Kadar Gula Darah Puasa (GDP)

Tabel 6

Hasil uji beda antara gula darah puasa (GDP) sebelum dan sesudah intervensi farmasis pada kelompok kontrol dan intervensi

\begin{tabular}{|c|c|c|c|c|c|c|}
\hline \multirow{3}{*}{ GDP } & \multicolumn{6}{|c|}{$\begin{array}{c}\text { Kelompok } \\
\end{array}$} \\
\hline & \multicolumn{3}{|c|}{$\begin{array}{c}\text { Kontrol }(\mathrm{n}=40) \\
\text { Puskesmas Kedaton }\end{array}$} & \multicolumn{3}{|c|}{$\begin{array}{l}\text { Intervensi }(\mathbf{n}=40) \\
\text { Puskesmas Satelit }\end{array}$} \\
\hline & pre & post & Sig & pre & post & Sig \\
\hline Rata-rata & $\begin{array}{r}145,8 \\
\pm 30,3\end{array}$ & $\begin{array}{r}137,3 \\
\pm 26,7\end{array}$ & $\mathbf{0 , 2 8 5}$ & $\begin{array}{r}155,9 \\
\pm 21,1\end{array}$ & $\begin{array}{r}139,8 \\
\pm 33,3\end{array}$ & $\mathbf{0 , 0 1 1}$ \\
\hline Terkendali Baik $(80$-> $100 \mathrm{mg} / \mathrm{dl})$ & 1 & 1 & & 0 & 5 & \\
\hline
\end{tabular}


Dewi Laxmi, Shirly Kumala, Prih Sarnianto dan Asnah Tarigan

\begin{tabular}{lccccc}
\hline $\begin{array}{l}\text { Terkendali Sedang }(100-125 \\
\mathrm{mg} / \mathrm{dl})\end{array}$ & 8 & 14 & & 3 & 10 \\
\hline Terkendali Buruk $(\geq 126 \mathrm{mg} / \mathrm{dl})$ & 31 & 25 & & 37 & 25 \\
\hline
\end{tabular}

Tabel 7

Hasil perbedaan kadar gula darah puasa (GDP) pada kelompok kontrol dan intervensi dengan uji Mann Whitney

\begin{tabular}{ccccc}
\hline \multirow{2}{*}{ Variabel } & & \multicolumn{2}{c}{ Kelompok } & \multirow{2}{*}{ Sig } \\
\cline { 2 - 4 } & & Kontrol & Intervensi & \multirow{2}{*}{$\begin{array}{l}\text { Pre } \\
\text { Nilai rata-rata GDP } \\
\begin{array}{c}\text { (kadar glukosa } \\
\text { puasa) }\end{array}\end{array}$} \\
\cline { 2 - 5 } & Rata-rata nilai selisih & $-8,525$ & $-16,05$ & $\mathbf{0 , 2 4 4}$ \\
\hline
\end{tabular}

Pada grafik 3 terlihat adanya penurunan rata-rata nilai GDP pada kelompok intervensi sebelum dan sesudah diberikan konseling yaitu sebesar 16,05, sedangkan pada kelompok kontrol terjadi penurunan rata-rata nilai GDP yaitu sebesar 8,52.

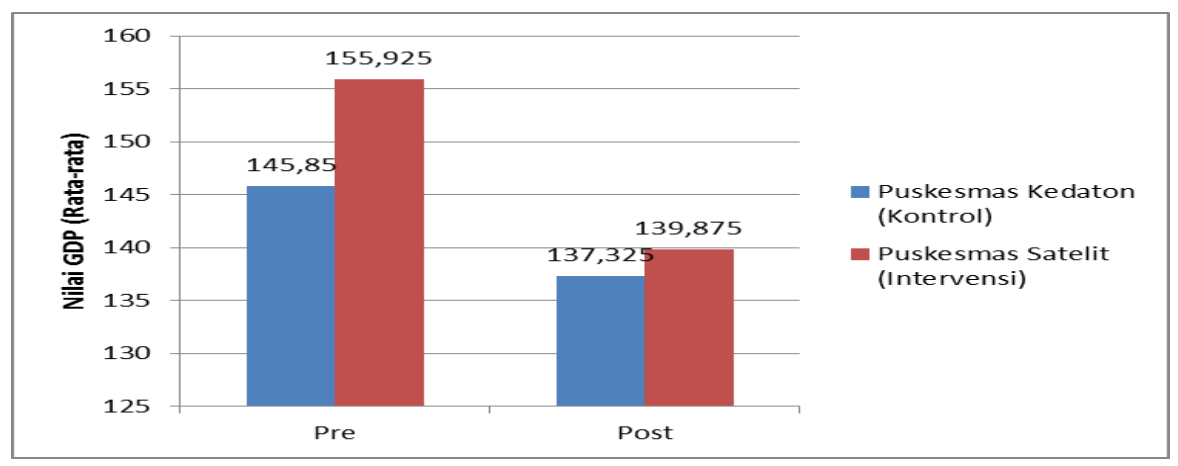

Grafik 3

Perbedaan kadar gula darah puasa (GDP) pasien berdasarkan rerata sebelum dan setelah konseling farmasis

Dari hasil uji wilcoxon pada kelompok intervensi diperoleh nilai p-value adalah 0,011 $(\mathrm{p}<0,05)$ yang menunjukkan terdapat perbedaan nilai GDP yang signifikan sebelum dan setelah konseling farmasis, sedangkan pada kelompok kontrol diperoleh nilai signifikansi sebesar 0,285 ( $\mathrm{p}>0,05)$ yang menunjukkan tidak terdapat perbedaan yang signifikan pada kelompok kontrol pada hasil pengukuran nilai GDP sebelum dan sesudah dilakukan penelitian. Dari hasil uji mann whitney diperoleh signifikansi sebesar 0,244 $(\mathrm{p}<0,05)$ yang menunjukkan bahwa tidak terdapat perbedaan nilai GDP yang signifikan antara kelompok kontrol dan kelompok intervensi. Pada penelitian ini menggambarkan bahwa konseling yang diberikan farmasis kepada pasien mempunyai pengaruh terhadap penurunan kadar gula darah puasa, akan tetapi penurunan nilai GDP pada kelompok intervensi yang 
diberikan konseling tidak berbeda signifikan dengan kelompok kontrol yang tidak diberikan konseling. Kadar GDP dapat dijadikan pedoman dalam diagnosis DM. Jika hasil pemeriksaan kadar GDP $\geq 126 \mathrm{mg} / \mathrm{dl}$ dan terdapat keluhan khas DM, diagnosis DM dapat ditegakkan (Adnan, Mulyati, \& Isworo, 2013). Juga terdapat penelitian di Puskesmas Kramat Jati Jakarta dengan hasil ada perbedaan yang bermakna sebelum dan setelah intervensi farmasi terhadap pengetahuan, kepatuhan dan kadar GDP dan GDPP (N, 2015).

\section{d. Kadar Gula Darah Setelah Makan (GDPP)}

Dari hasil uji wilcoxon pada kelompok intervensi diperoleh nilai p-value adalah 0,000 ( $\mathrm{p}<0,05)$ yang menunjukkan terdapat perbedaan nilai GDPP yang signifikan sebelum dan setelah konseling farmasis, sedangkan pada kelompok kontrol diperoleh nilai signifikansi sebesar 0,021 ( $\mathrm{p}>0,05)$ yang menunjukkan terdapat perbedaan yang signifikan pada kelompok kontrol pada hasil pengukuran nilai GDPP sebelum dan sesudah dilakukan penelitian.

\section{Tabel 8}

Hasil uji beda GDPP antara sebelum dan sesudah intervensi

\begin{tabular}{|c|c|c|c|c|c|c|}
\hline \multirow{3}{*}{ GDPP } & \multicolumn{6}{|c|}{ Kelompok } \\
\hline & \multicolumn{3}{|c|}{$\begin{array}{c}\text { Kontrol }(n=40) \\
\text { Puskesmas Kedaton }\end{array}$} & \multicolumn{3}{|c|}{$\begin{array}{l}\text { Intervensi }(\mathbf{n}=40) \\
\text { Puskesmas Satelit }\end{array}$} \\
\hline & pre & post & Sig & Pre & post & Sig \\
\hline Rata-rata & 196,3 & 182,2 & $\mathbf{0 , 0 2 1}$ & 191,6 & 154,6 & 0,000 \\
\hline Terkendali Baik $(80-144 \mathrm{mg} / \mathrm{dl})$ & 1 & 4 & & 0 & 17 & \\
\hline $\begin{array}{l}\text { Terkendala Sedang }(145-179 \\
\mathrm{mg} / \mathrm{dl})\end{array}$ & 10 & 18 & & 13 & 15 & \\
\hline Terkendali buruk $(\geq 180 \mathrm{mg} / \mathrm{dl})$ & 29 & 18 & & 27 & 8 & \\
\hline
\end{tabular}

Tabel 9

Hasil perbedaan kadar gula darah setelah makan (GDPP) pada kelompok kontrol dan intervensi dengan uji Mann Whitney

\begin{tabular}{|c|c|c|c|c|}
\hline \multirow{2}{*}{\multicolumn{2}{|c|}{ Variabel }} & \multicolumn{2}{|c|}{ Kelompok } & \multirow{2}{*}{ Sig } \\
\hline & & Kontrol & Intervensi & \\
\hline \multirow{3}{*}{$\begin{array}{c}\text { Nilai rata-rata GDPP } \\
\text { (kadar glukosa } 2 \text { jam pp) }\end{array}$} & Pre & 196,3 & 191,6 & \\
\hline & Post & 182,275 & 154,625 & \\
\hline & Rata-rata nilai selisih & $-14,025$ & $-36,975$ & 0,006 \\
\hline
\end{tabular}




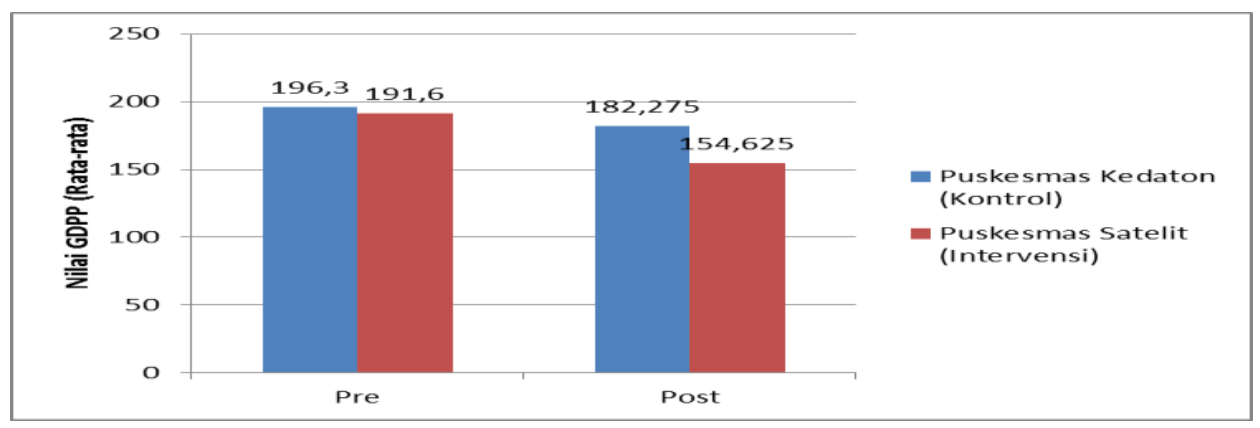

\section{Grafik 4}

Perbedaan kadar gula darah setelah makan (GDPP) pasien berdasarkan rerata sebelum dan setelah konseling farmasis

Dari hasil uji mann whitney diperoleh signifikansi sebesar $0,006(\mathrm{p}<0,05)$ yang menunjukkan bahwa terdapat perbedaan nilai GDPP yang signifikan antara kelompok kontrol dan kelompok intervensi. Pada penelitian ini menggambarkan bahwa baik kelompok intervensi yang diberikan konseling maupun kelompok kontrol yang tidak diberi konseling terjadi penurunan penurunan yang signifikan, akan tetapi kelompok intervensi yang diberikan konseling lebih dapat menurunkan kadar GDPP daripada kelompok kontrol.

\section{e. Kualitas Hidup}

Dari hasil uji wilcoxon pada kelompok intervensi diperoleh nilai p-value adalah $0,000(\mathrm{p}<0,05)$ yang menunjukkan terdapat perbedaan nilai kualitas hidup yang signifikan sebelum dan setelah konseling farmasis, sedangkan pada kelompok kontrol diperoleh nilai signifikansi sebesar 0,397 ( $p>0,05)$ yang menunjukkan tidak ada perbedaan yang signifikan pada kelompok kontrol pada hasil pengukuran nilai kualitas hidup sebelum dan sesudah dilakukan penelitian. Dari hasil uji mann whitney diperoleh signifikansi sebesar 0,001 $(\mathrm{p}<0,05)$ yang menunjukkan bahwa terdapat perbedaan nilai kualitas hidup yang signifikan antara kelompok kontrol dan kelompok intervensi. Perbedaan nilai kualitas hidup antara kelompok intervensi dan kelompok kontrol menggambarkan bahwa konseling yang diberikan kepada pasien prolanis tipe 2 dapat meningkatkan kualitas hidup pasien tersebut.

Hasil penelitian ini sesuai dengan hasil penelitian yang dilakukan di Puskesmas Gedong Tengen dengan hasil yang signifikan antara konseling farmasi yang dilakukan dengan meningkatnya kualitas hidup pasien diabetes melitus tipe 2 (Septiar \& Utami, 2015). 
Tabel 10

Hasil uji beda antara kualitas hidup sebelum dan sesudah intervensi farmasis pada kelompok kontrol dan intervensi

\begin{tabular}{|c|c|c|c|c|c|c|}
\hline \multirow{3}{*}{ Kualitas Hidup } & \multicolumn{6}{|c|}{ Kelompok } \\
\hline & \multicolumn{3}{|c|}{$\begin{array}{c}\text { Kontrol }(\mathrm{n}=40) \\
\text { Puskesmas Kedaton }\end{array}$} & \multicolumn{3}{|c|}{$\begin{array}{l}\text { Intervensi }(n=40) \\
\text { Puskesmas Satelit }\end{array}$} \\
\hline & pre & post & Sig & pre & post & Sig \\
\hline Rata-rata & $\begin{array}{r}58,5 \\
\pm 11,2 \\
\end{array}$ & $\begin{array}{r}59,1 \\
\pm 9,84 \\
\end{array}$ & 0,397 & $\begin{array}{c}54,8 \\
\pm 8,89 \\
\end{array}$ & $\begin{array}{r}63,8 \\
\pm 7,9\end{array}$ & 0,000 \\
\hline Baik sekali $(76-100)$ & 2 & 2 & & 0 & 2 & \\
\hline Baik $(51-75)$ & 25 & 29 & & 27 & 35 & \\
\hline Cukup $(26-50)$ & 13 & 9 & & 13 & 3 & \\
\hline Kurang $(0-25)$ & 0 & 0 & & 0 & 0 & \\
\hline
\end{tabular}

Tabel 11

Hasil perbedaan kualitas hidup pada kelompok kontrol dan intervensi dengan uji Mann Whitney

\begin{tabular}{|c|c|c|c|c|}
\hline \multirow{2}{*}{\multicolumn{2}{|c|}{ Variabel }} & \multicolumn{2}{|c|}{ Kelompok } & \multirow{2}{*}{ Sig } \\
\hline & & Kontrol & Intervensi & \\
\hline \multirow{3}{*}{$\begin{array}{l}\text { Nilai Rata-rata } \\
\text { Kualitas Hidup }\end{array}$} & Pre & 58,575 & 54,8 & \\
\hline & Post & 59,15 & 63,8 & \\
\hline & Rata-rata nilai selisih & 0,575 & 9 & 0,001 \\
\hline
\end{tabular}

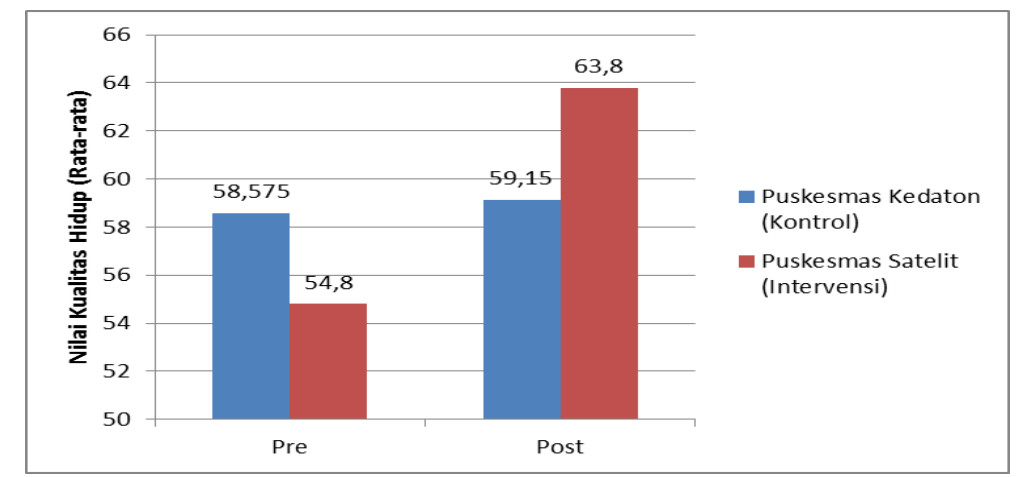

Grafik 5

Perbedaan kualitas hidup pasien berdasarkan rerata sebelum dan setelah konseling farmasis

3. Hubungan antara Tingkat Pengetahuan, Kepatuhan, Kadar Glukosa Darah, dan Kualitas Hidup

Tujuan selanjutnya dari penelitian ini adalah untuk mengetahui hubungan antara tingkat pengetahuan, kepatuhan, kadar glukosa darah, dan kualitas hidup. Confounding factor merupakan variabel yang dapat mengganggu. Confounding factor yang dianalisa antara lain adalah usia, pendidikan, pekerjaan, jenis kelamin, dan DM karena kemungkinan dapat mempengaruhi nilai pengetahuan, kepatuhan, kadar glukosa darah 
dan kualitas hidup. Pengaruh confounding factor dengan pengetahuan, kepatuhan, kadar glukosa dan kualitas hidup diuji dengan Spearmans rho correlation.

\section{Tabel 12}

Nilai signifikansi antara confounding factor dan variabel pada kelompok kontrol

\begin{tabular}{cccccc}
\hline Confounding & \multicolumn{5}{c}{ Variabel } \\
\cline { 2 - 6 } factor & Pengetahuan & Kepatuhan & GDP & GDPP & Kualitas Hidup \\
\hline Usia & 0,977 & 0,505 & 0,814 & 0,561 & 0,055 \\
\hline Pendidikan & 0,611 & 0,791 & 0,071 & 0,112 & 0,293 \\
\hline Pekerjaan & 0,149 & 0,109 & 0,578 & 0,422 & 0,683 \\
\hline Jenis Kelamin & 0,149 & 0,109 & 0,578 & 0,422 & 0,683 \\
\hline Durasi diabetes & 0,285 & 0,326 & 0,297 & 0,886 & 0,762 \\
\hline
\end{tabular}

Hasil uji Spearmans rho correlation pada confounding factor adalah bila nilai Sig lebih kecil dari 0,05 maka confounding factor berhubungan dengan pengetahuan, kepatuhan, kadar glukosa darah dan kualitas hidup. Bila nilai Sig lebih besar dari 0,05 maka confounding factor tidak ada hubungan dengan pengetahuan, kepatuhan, kadar glukosa darah dan kualitas hidup. Pada tabel 12 dan tabel 13. Semua nilai signifikansi lebih kecil dari 0,05 yang menunjukkan bahwa confounding factor yang terdiri dari usia, pendidikan, pekerjaan, jenis kelamin, dan durasi diabetes mellitus tidak ada hubungan dengan pengetahuan, kepatuhan, kadar glukosa darah dan kualitas hidup. Penelitian ini tidak searah dengan penelitian-penelitian yang telah dilakukan sebelumnya menyatakan bahwa sosiodemografi, faktor perilaku dan gaya hidup serta keadaan klinis atau mental berpengaruh terhadap kejadian diabetes melitus (25). Adanya perbedaan pada hasil penelitian dapat disebabkan oleh kondisi pasien yang telah mengikuti program prolanis pada umumnya menerima kondisinya sebagai penderita DM dan lebih memiliki keinginan tinggi untuk mempertahankan kesehatan.

\section{Tabel 13}

Nilai signifikansi antara confounding factor dan variabel pada kelompok intervensi

\begin{tabular}{cccccc}
\hline Confounding & \multicolumn{5}{c}{ Variabel } \\
\cline { 2 - 6 } factor & Pengetahuan & Kepatuhan & GDP & GDPP & Kualitas Hidup \\
\hline Usia & 0,325 & 0,845 & 0,382 & 0,878 & 0,743 \\
\hline Pendidikan & 0,270 & 0,616 & 0,842 & 0,070 & 0,114 \\
\hline Pekerjaan & 0,920 & 0,688 & 0,304 & 0,887 & 0,943 \\
\hline Jenis Kelamin & 0,920 & 0,688 & 0,304 & 0,887 & 0,943 \\
\hline Durasi diabetes & 0,423 & 0,103 & 0,368 & 0,146 & 0,287 \\
\hline
\end{tabular}

Tujuan selanjutnya dari penelitian ini adalah untuk mengetahui hubungan antara tingkat pengetahuan, kepatuhan, kadar glukosa darah, dan kualitas hidup. Uji analisa 
bivariate dengan metode Spearmans rho correlation dilakukan untuk melihat korelasi atau hubungan antara pengetahuan, kepatuhan, kadar glukosa darah, dan kualitas hidup. Di bawah ini dapat dilihat hasil korelasi antara pengetahuan, kepatuhan, kadar glukosa, dan kualitas hidup pada kelompok intervensi dan kelompok kontrol.

Nilai korelasi pada tabel 14 merupakan hasil selisih dari data setelah dengan sebelum intervensi farmasis pada variabel pengetahuan, kepatuhan, kadar glukosa darah, dan kualitas hidup. Intervensi farmasis adalah dalam bentuk wawancara dan brief counselling. Pada penelitian ini menunjukkan bahwa nilai Sig yang dihasilkan pada kelompok kontrol lebih dari 0,05 dengan hasil korelasi pengetahuan dengan kepatuhan 0,866, korelasi pengetahuan dengan GDP 0,821, korelasi pengetahuan dengan GDPP 0,390, korelasi pengetahuan dengan kualitas hidup 0,309, korelasi kepatuhan dengan kadar GDP 0,469, korelasi kepatuhan dengan kadar GDPP 0,873, dan korelasi kepatuhan dengan kualitas hidup 0,519. Hasil uji korelasi Spearmans rho correlation pada kelompok kontrol ini tidak menggambarkan adanya korelasi antara pengetahuan, kepatuhan, kadar glukosa darah, dan kualitas hidup.

Pada kelompok intervensi menunjukkan nilai Sig. kurang dari 0,05 dengan hasil korelasi pengetahuan dengan kepatuhan sebesar 0,000 , korelasi pengetahuan dengan GDP 0,015, korelasi pengetahuan dengan GDPP 0,000, korelasi pengetahuan dengan kualitas hidup 0,005, korelasi kepatuhan dengan kadar GDP 0,000, korelasi kepatuhan dengan kadar GDPP 0,000, dan korelasi kepatuhan dengan kualitas hidup 0,003. Hasil korelasi pada kelompok intervensi menggambarkan bahwa terdapat korelasi antara pengetahuan dengan kepatuhan, GDP, GDPP, dan kualitas hidup, serta terdapat korelasi antara kepatuhan dengan GDP, GDPP, dan kualitas hidup.

\section{Tabel 14}

Hasil korelasi pada kelompok kontrol dan kelompok intervensi dengan menggunakan uji Spearmans rho correlation

\begin{tabular}{|c|c|c|c|c|}
\hline \multirow{3}{*}{ Variabel } & \multicolumn{4}{|c|}{ Kelompok } \\
\hline & \multicolumn{2}{|c|}{ Kontrol } & \multicolumn{2}{|c|}{ Intervensi } \\
\hline & Nilai rata-rata & Sig & Nilai rata-rata & Sig \\
\hline Pengetahuan & 27,6 & \multirow{2}{*}{0,866} & 31,5 & \multirow{2}{*}{0,000} \\
\hline Kepatuhan & 5,1 & & 6,7 & \\
\hline Pengetahuan & 27,6 & \multirow{2}{*}{0,821} & 31,5 & \multirow{2}{*}{$\mathbf{0 , 0 1 5}$} \\
\hline GDP & 137,3 & & 139,8 & \\
\hline Pengetahuan & 27,6 & \multirow{2}{*}{0,390} & 31,5 & \multirow{2}{*}{0,000} \\
\hline GDPP & 182,2 & & 154,6 & \\
\hline Pengetahuan & 27,6 & \multirow{2}{*}{0,309} & 31,5 & \multirow{2}{*}{0,005} \\
\hline Kualitas Hidup & 59,1 & & 63,8 & \\
\hline Kepatuhan & 5,1 & \multirow{2}{*}{0,469} & 6,7 & \multirow{2}{*}{0,000} \\
\hline GDP & 137,3 & & 139,8 & \\
\hline Kepatuhan & 5,1 & $\mathbf{0 , 8 7 3}$ & 6,7 & 0,000 \\
\hline
\end{tabular}




\begin{tabular}{lcccc} 
GDPP & 182,2 & & 154,6 \\
\cline { 1 - 1 } Kepatuhan & 5,1 & \multirow{2}{*}{$\mathbf{0 , 5 1 9}$} & 6,7 & \multirow{2}{*}{003} \\
\cline { 1 - 1 } Kualitas Hidup & 59,1 & & 63,8 & \multirow{2}{*}{} \\
\hline
\end{tabular}

Pada kelompok intervensi dari hasil korelasi menunjukkan bahwa tingkat pengetahuan pasien berpengaruh signifikan terhadap kepatuhan, hasil terapi, dan kualitas hidup. Pengetahuan pasien tentang penyakit, pengobatannya serta efek-efek yang ditimbulkan dari penyakit itu akan mempengaruhi tingkat kepatuhan, hasil terapi, dan kualitas hidup dari pasien tersebut. Pengetahuan yang terus meningkat akan membuat level kepatuhan meningkat, sehingga hasil terapi dan kualitas hidup dari pasien tersebut akan meningkat pula. Pada penelitian ini walaupun kebanyakan pasiennya berlatar belakang Sekolah Dasar (SD) tetapi hasil terapi dan kualitas hidup mereka meningkat. Hal ini menunjukkan pentingnya farmasis ikut berperan aktif memberikan pelayanan konseling yang optimal sehingga mempengaruhi pengetahuan dan cara pandang mereka tentang kesehatan khususnya tentang penyakit diabetes mellitus yang dideritanya dan selanjutnya meningkatkan kepatuhan, sehingga keberhasilan terapi dan kualitas hidup yang baik pun akan tercapai. Hal ini sejalan dengan penelitian sebelumnya yang menyimpulkan bahwa asuhan kefarmasian dapat meningkatkan kepatuhan, kualitas hidup dan keterkendalian GDP kualitas hidup pasien DM 2 peserta Prolanis dan non-Prolanis (Yeshi Mayasari, 2020).

\section{Kesimpulan}

Konseling farmasis memberikan pengaruh yang signifikan setelah pasien diberikan konseling terhadap pengetahuan, kepatuhan, GDP, GDPP, dan kualitas hidup. Hal ini menunjukkan konseling yang diberikan farmasis dapat meningkatkan pengetahuan dan kepatuhan sehingga tercapai kadar gula darah dan kualitas hidup yang optimal.

Terdapat perbedaan bermakna antara kelompok intervensi dan kelompok kontrol pada tingkat pengetahuan, kepatuhan, GDPP, dan kualitas hidup, sedangkan pada GDP tidak ada perbedaan yang bermakna. Terlihat pula adanya hubungan antara pengetahuan, kepatuhan, kadar gula darah, dan kualitas hidup. Hal ini membuktikan dengan adanya konseling oleh farmasis dapat meningkatkan pengetahuan, dan kepatuhan pasien diabetes melitus tipe II sehingga tercapai hasil terapi dan kualitas hidup yang optimal. 
Pengaruh Edukasi Farmasis terhadap Hasil Terapi dan Kualitas Hidup Pasien Prolanis

Diabetes Melitus Tipe 2

\section{BIBLIOGRAFI}

Adnan, Miftahul, Mulyati, Tatik, \& Isworo, Joko Teguh. (2013). Hubungan Indeks Massa Tubuh (IMT) dengan kadar gula darah penderita diabetes mellitus (DM) tipe 2 rawat jalan di RS Tugurejo Semarang. Jurnal Gizi, 2(1).

Creed, Francis, Ratcliffe, Joy, Fernandez, Lakshmi, Tomenson, Barbara, Palmer, Steve, Rigby, Christine, Guthrie, Elspeth, Read, Nicholas, \& Thompson, David. (2001). Health-related quality of life and health care costs in severe, refractory irritable bowel syndrome. Annals of Internal Medicine, 134(9_Part_2), 860-868.

Federation, Internasional Diabetes. (2015). Idf diabetes atlas 2013. Brussels: Belgium.

Indonesia, Kementerian Kesehatan Republik. (2013). Hasil Riset Kesehatan Dasar [Internet]. Retrieved from www.depkes.go.id/resources/download/general/Hasil Riskesdas. Diakses pada tanggal 15 September 2014

Irawan, Dedi. (2010). Prevalensi dan Faktor Risiko Kejadian Diabetes Melitus Tipe 2 di Daerah Urban Indonesia (Analisa Data Sekunder Riskesdas 2007). Thesis Universitas Indonesia.

Kementerian Kesehatan RI. (2020). Tetap Produktif, Cegah dan Atasi Diabetes Melitus. ISSN 2442-7659. Infodatin. Pusat Data dan Informasi Kementerian Kesehatan RI., Jakarta. Diakses pada tanggal 18 Januari 2021 melalui https://pusdatin.kemkes.go.id/download.php?file=download/pusdatin/infodatin/infodat in-Diabetes-2018.pdf

Lampung, inas Kesehatan Kota Bandar. (2015). Profil Kesehatan Kota Bandar Lampung Tahun 2016. Bandar Lampung: Dinas Kesehatan Kota Bandar Lampung.

Mayasari Yeshi. Prih Sarnianto dan Yusi Anggriani (2020). Pengaruh Asuhan Kefarmasian terhadap Kualitas Hidup Pasien Diabetes Melitus Tipe 2 Di Dua Puskesmas Daerah Jakarta Timur. Syntax Literate: Jurnal Ilmiah Indonesia p-ISSN: 2541-0849, e-ISSN: 2548-1398. Vol.5, No. 6, Juni 2020. Diakses melalui http://jurnal.syntaxliterate.co.id/index.php/syntax-literate/article/view/1338 pada 18 Januari 2021.

Merlin, Radoti, Arozal, Wawaimuli, Sauriasari, Rani, \& Keban, Sesilia. (2017). Evaluasi Penerapan Booklet dan Edukasi Apoteker pada Pasien Diabetes Melitus Tipe 2 di Rumah Sakit Mayapada Tangerang. Pharmaceutical Sciences and Research (PSR), $4(2), 102-110$.

Mongisidi, Gabby. (2014). Hubungan antara status sosio-ekonomi dengan kejadian diabetes mellitus tipe 2 di Poliklinik Interna BLU RSUP Prof. Dr. RD Kandou Manado. Repository Unsrat. Jurnal Ilmiah (Online)(Http://Fkm. Unsrat. Ac. Id/Wp- 
Dewi Laxmi, Shirly Kumala, Prih Sarnianto dan Asnah Tarigan

Content/Uploads/2015/02/Januari-Gabby-Mongisidi. Pdf, Diakses Pada Tanggal 29 Januari 2018).

Morisky, Donald E., Ang, Alfonso, Krousel-Wood, Marie, \& Ward, Harry J. (2008). Predictive validity of a medication adherence measure in an outpatient setting. The Journal of Clinical Hypertension, 10(5), 348-354.

N, Voni. (2015). Pengaruh edukasi dan homecare oleh farmasis pada pasien diabetes melitus tipe 2 di Puskesmas Kramat Jati Jakarta Timur periode Oktober - Desember 2015 [tesis]. Fakultas Farmasi Universitas Pancasila., Jakarta.

Rifqi R, Chlara N, Rakta R. (2015). Pengaruh pemberian homecare oleh apoketer pada pasien diabetes melitus. Jurnal Management Dan Pelayanan Farmasi. Universitas Gadjah Mada.

Septiar, Handaka Ekaningputra, \& Utami, Pinasti. (2015). Pengaruh Konseling Farmasis Terhadap Kualitas Hidup dan Kadar Gula Darah Pada Pasien Diabetes Mellitus Tipe 2 di Puskesmas Gedong Tengen Periode Maret-Mei 2014. Jurnal Farmasi Sains Dan Praktis, 1(1), 29-34.

Zakaria, Nurul Husna, Mohamed, Nik Mohd Zuki Nik, Ab Rahid, Mohd Fadzil Faisae, \& Rose, Ahmad Nasser Mohd. (2017). Lean manufacturing implementation in reducing waste for electronic assembly line. MATEC Web of Conferences, 90, 1048. EDP Sciences. 